\title{
STUDI LEKSIKAL TERHADAP KATA 'KEHILANGAN' DALAM ROMA 3:23
}

\author{
Adi Putra
}

Beberapa kali saya mendengar ada pendeta yang berkata, karena dosa makanya manusia "kehilangan kemuliaan Allah" dan argumen itu didasarkan kepada teks dalam Roma 3:23. Sepertinya ajaran ini mengusik saya dan membuat saya tertarik untuk menelitinya lebih lanjut. Menurut Thomas van den End, "Menurut Paulus di sini kemuliaan itu adalah kemuliaan Allah, yang berhubungan erat dengan kekudusan Allah" (Th. van den End, hlm. 180). Dan menurut saya kekudusan Allah ini tidak dapat dilepaskan dari gambar Allah yang juga disandang oleh manusia. Dan menurut saya, "Tidak mungkin manusia yang diciptakan segambar dan serupa dengan Allah akan kehilangan kemuliaan Allah”.

Oleh karena apabila terjadi demikian, maka itu sama saja kita mengatakan bahwa dosa membuat gambar Allah itu hilang. Konsekuensinya adalah semua manusia bukan lagi gambar dan rupa Allah. Lalu, apa yang dipulihkan oleh Yesus Kristus? Bukankah gambar Allah itulah yang dipulihkan kembali oleh Kristus dalam penebusan yang dilakukan oleh-Nya. Namun karena saya tidak mau terjebak dalam teologi saya, maka saya mencoba meneliti sendiri dengan memperhatikan teks Roma 3:23.

Roma 3:23 berbunyi: "Karena semua orang telah berbuat dosa dan telah kehilangan kemuliaan Allah". Kata $\dot{\sigma \tau \varepsilon \rho \varepsilon ́ \omega ~ d i t e r j e m a h k a n ~ o l e h ~ L A I ~(T B) ~ d e n g a n ~ k e h i l a n g a n . ~ B a u e r ' s ~}$ Danker memberikan beberapa arti dari kata ini, yakni:

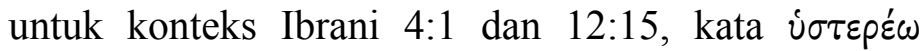
sebaiknya dipahami sebagai melewatkan sesuatu [sebagai konsekuensi] dari kesalahan sendiri; ketinggalan atau gagal mencapai. Untuk konteks Yohanes 2:3 dan Markus 10:21, kata ini harus dipahami sebagai berada dalam pasokan yang kurang; gagal; memberikan; kekurangan. Untuk

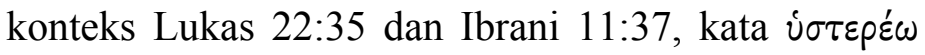
sebaiknya dipahami berada dalam keadaan membutuhkan, menjadi miskin, kurangnya. Untuk konteks 2 Korintus 11:5; 12:11; atau 1 Korintus 12:24; kata ini sebaiknya dipahami dalam status menjadi lebih rendah; kurang dari atau lebih rendah. Dan terakhir untuk konteks Matius 19:20; 1 Korintus 1:7; 8:8; 12:24; Lukas 15:14; 2 Korintus 11:9; Flp.

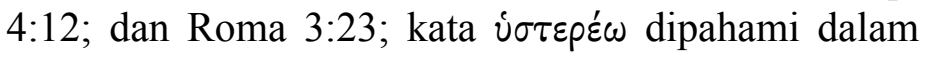
pengertian mengalami kekurangan sesuatu yang

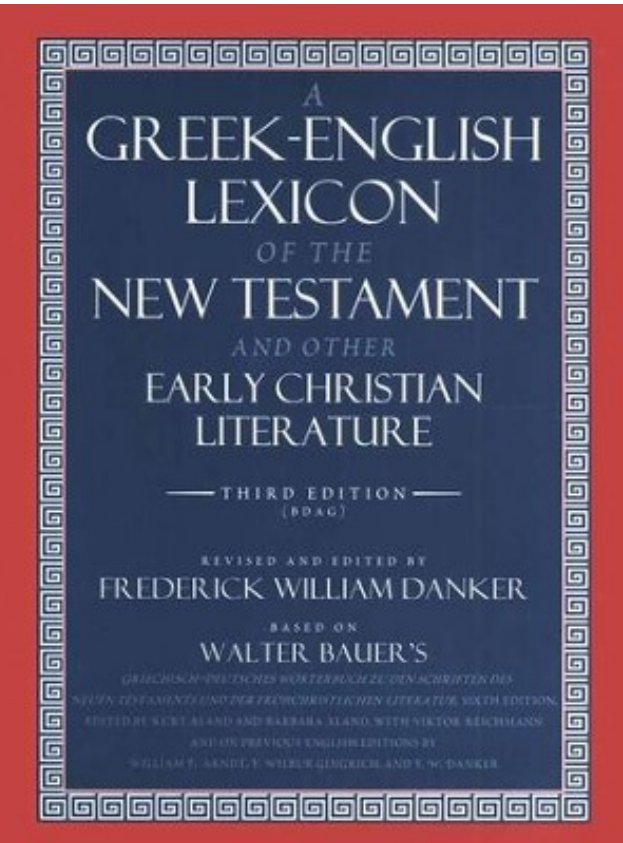
menguntungkan atau seperti yang diinginkan; kurang; menjadi kekurangan; pergi tanpa; atau kekurangan, (band. BDAG, pp.1043-44).

Memang pengertian yang diberikan oleh Bauer dalam setiap konteks kitab atau perikop di mana kata ini digunakan; juga terlihat jelas dalam keragaman dari terjemahan yang

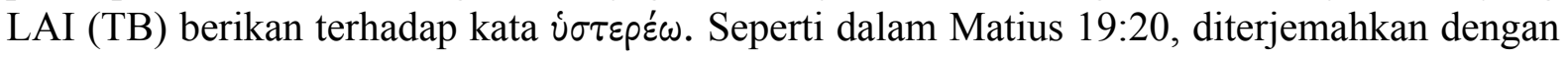
kurang; dalam Markus 10:21 juga diterjemahkan dengan kekurangan (band. dalam Luk.15:14 - melarat; Luk.22:35, Yoh.2:3, 1 Kor. 1:7, 2 Kor.11:5,9, Flp.4:12, Ibr. 11:37 kekurangan; 1 Kor.12:24 - tidak mulia; dan Ibr. 12:15 - menjauhkan dari). 


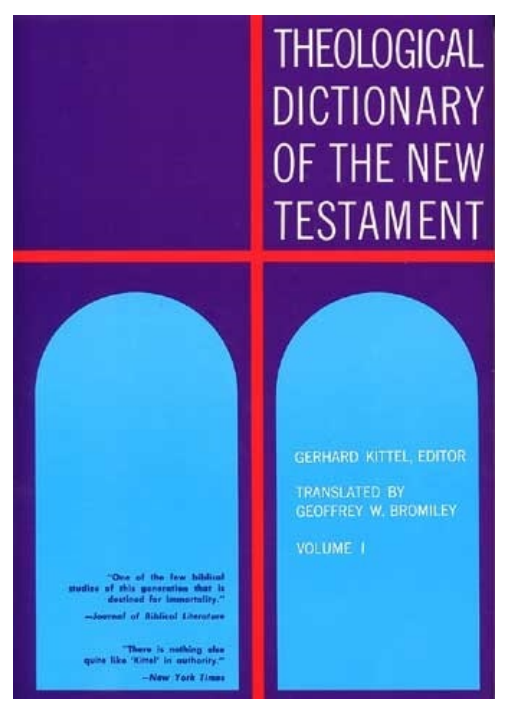

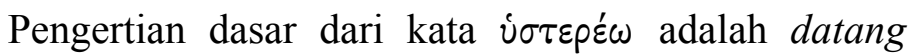
terlambat atau gagal mencapai; di mana muncul dua kali dalam Ibrani 4:1, berisi tentang sebuah peringatan eskatologis untuk tidak salah dalam mencapai hasil dari janji karena kekurangan iman. Dalam Ibrani 12:15, memperingatkan supaya melawan kegagalan untuk mencapai anugerah Allah karena tidak menjaga perdamaian dan mengejar pengudusan (ay.14). Sedangkan diskusi dalam Roma 1:18-3:20, Paulus menyimpulkannya, kita semua telah gagal dalam kemuliaan Allah (ay.23) dan dengan demikian bergantung pada kasih karunia yang membenarkan melalui karya Kristus yang menjadikan baik setiap kerugian dan mencapai pemuliaan kita (band. $5: 2 ; 8: 17-18,29-30 ; 9: 23 ; 1$ Tes.2:12). Dalam Markus 10:21, Tuhan Yesus menegaskan juga tentang keadaan yang dimaksud dari kata $\dot{\sigma \tau \varepsilon \rho \varepsilon ́ \omega . ~}$

Dalam perikop itu, disebutkan bahwa ada seorang muda yang kaya namun tidak memiliki sesuatu yang dapat membawanya untuk masuk ke dalam kehidupan yang kekal (Kerajaan Surga). Dalam Mat.19:20-21, Tuhan Yesus berkata kepada orang muda yang kaya bahwa, masih ada sesuatu yang perlu untuk ditambahkan kepadanya supaya dapat masuk dalam Kerajaan Surga; bukan yang kurang itu menjadi absolut (band. Yoh. 2:3), (bdk. TDNT, p. 1241).

Berdasarkan pengertian leksikal dan penggunaan kata $\dot{\sigma \tau \varepsilon \rho \varepsilon ́ \omega}$ dalam beberapa kitab khususnya dalam PB, maka untuk konteks Roma 3:23 [yang dipahami oleh Kittel sebagai sebuah kesimpulan dari uraian Paulus dari 1:18-3:20], kata $\dot{\sigma \tau \varepsilon \rho \varepsilon ́ \omega ~ s e b a i k n y a ~ d i p a h a m i ~}$ bahwa telah terjadi kekurangan sesuatu yang menguntungkan bagi manusia yang disebabkan oleh dosa - sehingga pascaberdosa manusia berada dalam keadaan yang tidak sempurna karena telah kekurangan sesuatu (kemuliaan).

Apabila memperhatikan kisah seorang muda yang kaya dalam Matius 19:16-22; maka dapat disimpulkan bahwa kurangnya kemuliaan Allah pada manusia dapat menyebabkan putusnya persekutuan antara Allah dengan manusia - satu-satunya cara untuk dapat memulihkannya hanya melalui dan oleh Tuhan Yesus. Ketika kemuliaan itu kurang, maka semua kebaikan yang dilakukan oleh manusia tidak ada gunanya atau menjadi sia-sia. Sama seperti orang muda yang kaya di mana dia telah melakukan semua perbuatan baik berdasarkan tuntutan hukum Taurat - akan tetapi ternyata itu tidak mampu memulihkan kemuliaan Allah yang telah hilang atau rusak karena dosa pada dirinya. Kemuliaan Allah yang rusak itu hanya dapat dipulihkan melalui kasih karunia dari dan melalui karya Tuhan Yesus.

Dengan demikian, kehilangan kemuliaan Allah dalam konteks Roma 3:23 harus dipahami sebagai "kurangnya kemuliaan Allah" dan berdampak pada rusaknya persekutuan antara Allah dengan manusia. Sehingga mengancam manusia mengalami kebinasaan dalam kuasa maut. Namun karena melalui kasih karunia Allah di dalam Tuhan Yesus, sehingga memulihkan kemuliaan itu melalui karya penebusan yang dikerjakan-Nya secara sempurna di atas kayu salib.

\section{Literatur:}

Kittel, Gerhard., Gerhard Friedrich (Editor). Theological Dictionary of The New Testament (TDNT). Michigan: Wm. B. Eerdmans Publishing Company, 1976 (Diterjemahkan oleh: Geoffrey W. Bromiley). 
Bauer's, Walter. A Greek-English Lexicon of the New Testament on Other Early Christian Literature. Chicago dan London: The University of Chicago Press, 1957. (Direvisi dan Diedit oleh: Frederick William Danker).

van den End, Thomas, Tafsiran Alkitab: Surat Roma, Jakarta: BPK Gunung Mulia, 2006. 